\title{
Bacterial Meningitis: The Role of Transforming Growth Factor-Beta in Innate Immunity and Secondary Brain Damage
}

\author{
Ursula Malipiero $^{\mathrm{a}} \quad$ Uwe Koedel $^{\mathrm{b}} \quad$ Walter Pfister $^{\mathrm{b}} \quad$ Adriano Fontana $^{\mathrm{a}}$ \\ ${ }^{a}$ Clinics for Immunology, University Hospital Zurich, Zurich, Switzerland; ' Department of Neurology, \\ Klinikum Grosshadern, Ludwig Maximilians University, Munich, Germany
}

\section{Key Words}

Chemotaxis • Leukocytes · Endothelium • Vasculitis •

Inflammation

\begin{abstract}
Project 6 of the NCCR 'Neural Plasticity and Repair' focuses on mechanisms of immunity and tissue damage in autoimmune and infectious diseases of the central nervous system (CNS). In one of the subprojects, the influence of transforming growth factor- $\beta$ (TGF- $\beta$ ) on the immune reactivity of the CNS was investigated. In mice with Streptococcus pneumoniae-induced meningitis, a deletion of TGF- $\beta$ receptor II on leukocytes is found to enhance recruitment of neutrophils to the site of infection and to promote bacterial clearance. The improved host defense against S. pneumoniae was associated with an almost complete prevention of meningitisinduced vasculitis, a major intracranial complication leading to brain damage. The data show that endogenous TGF- $\beta$ suppresses host defense against bacterial infection in the CNS. This contrasts with findings from other body compartments that suggested that TGF- $\beta$ is a powerful chemotactic cytokine and increases microbial clearance.
\end{abstract}

Copyright $\odot 2007$ S. Karger AG, Basel (c) $2007 \mathrm{~S}$. Karger $\mathrm{AG}$, Basel

1660-2854/07/0041-0043\$23.50/0

Fax +4161306 1234

E-Mail karger@karger.ch

www.karger.com
Accessible online at:

www.karger.com/ndd
Transforming growth factor- $\beta$ (TGF- $\beta$ ) controls proliferation, differentiation, and the function of many types of cells. By these activities, TGF- $\beta$ plays a pivotal role in development, tissue homeostasis and tumor formation. The multiple actions of TGF- $\beta$ also influence the function of the innate and acquired immune system. In this brief review, we describe the functional role of TGF- $\beta$ in bacterial meningitis.

\section{Bacterial Meningitis}

At present, approximately 1.2 million cases of bacterial meningitis are estimated to occur annually worldwide resulting in 135,000 deaths. Bacterial meningitis is now a top 10 infectious cause of death worldwide and about half of the survivors have neurological sequelae of the disease. Despite antimicrobial agents and intensive care medicine, mortality and morbidity have remained high. With the introduction of Haemophilus influenzae conjugate vaccines in the United States and Western Europe, Streptococcus pneumoniae and Neisseria meningitides have become the major causes of bacterial meningitis in these regions. The mortality rate associated with pneumococcal meningitis is about $20-35 \%$ [1] versus $15-30 \%$ 
for Listeria monocytogenes. An analysis of 87 consecutive cases that were treated in the Department of Neurology, Klinikum Grosshadern in Munich showed intracerebral complications to occur in $75 \%$ with seizures (28\%), arterial cerebrovascular complications (22\%), venous complications (10\%), diffuse brain edema (29\%), and hydrocephalus (16\%) [2].

Clearance of bacteria in the central nervous system (CNS) which depends on a functional phagocyte system - polymorphonuclear neutrophils (PMN) and monocytes/macrophages - is limited due to low complement-mediated opsonic activity in the cerebrospinal fluid (CSF) and low complement $\mathrm{C} 4$ and $\mathrm{C} 3$ concentrations [3]. In meningitis, inflammation is seen in the meninges and leads to parenchymal damage in the brain and spinal cord, as evidenced by endothelial injury, increased vascular permeability, brain edema and neuronal damage. Bacterial cell wall components and toxins (released during antibiotic-induced or bacterial autolysis) enter into the CSF compartment and reach the interstitium of the CNS by paravascular fluid circulation. Besides the infectious pathogens, vascular damage and neurotoxicity are also caused by the host defense system. Recognition of microbial constituents is mediated through pattern recognition receptors of which Toll-like receptors (TLRs) are key participants [4]. TLRs recognize structural motifs referred to as pathogen-associated molecular patterns on the pathogens, a process initiating activation of PMN, monocyte-macrophages and natural killer cells. As a consequence, innate immunity results in the production of chemokines and proinflammatory cytokines [e.g. tumor necrosis factor (TNF- $\alpha$ ), interleukin (IL)-1 and IL-6], which initiate endothelial cell damage, recruitment of PMN and monocytes into the meninges and CNS tissue, activation of both astrocytes and microglia cells, and neuronal damage. TLR2 recognizes the pneumococcal cell wall molecule lipoteichoic acid whereas TLR4 acts as a ligand for the pneumococcal cytotoxin pneumolysin [references in ref. 5]. Mice that lack either TLR2, TLR4 or their downstream adaptor protein myeloid differentiation factor 88 show reduced CSF PMN pleocytosis, less inflammation but severely impaired bacterial clearance [5]. The production of TNF- $\alpha$, IL-1 and of the PMN chemokines MIP-2 and KC was significantly diminished [5]. Recent studies using anti-IL-6 antibodies and IL- 6 gene knockout mice showed IL- 6 to inhibit migration of PMN into the CNS but to promote vascular permeability, brain edema formation and rise in intracranial pressure [6]. In the breakdown of the blood-brain barrier nitric oxide plays a decisive role by modulating adhesiveness of PMN through inhibition of $\beta_{2}$-integrin expression. Impaired nitric oxide synthesis in mice with a deletion of the inducible nitric oxide synthase (iNOS) results in aggravated CSF pleocytosis [7]. The extent of the inflammatory process is limited by counterregulatory cytokines, namely IL-10 and TGF- $\beta$, which deactivate neutrophils and macrophages. These cytokines interfere with production of neurotoxic molecules by phagocytes, which include radical oxygen intermediates, nitric oxide and proteases such as matrix metalloproteinases (MMP). MMP8 and MMP9 are upregulated in the CSF in meningitis, MMP9 concentrations being higher in patients with secondary brain damage than in those who show complete recovery [8]. Besides MMP9, also high levels of the nitric oxide-induced oxidant peroxynitrite in the CSF are associated with an unfavorable outcome [9]. One of the pathways of oxidant-induced CNS damage includes poly(ADP ribose) polymerase, its deletion in mice improving the clinical score of meningitis [10].

\section{TGF- $\beta$ and Immune Response}

TGF- $\beta$ is part of the TGF- $\beta$ superfamily, with additional members including bone morphogenetic proteins, activins and growth differentiation factors. From the three homologous TGF- $\beta$ isoforms in mammals, it is TGF- $\beta_{1}$ that is predominantly expressed in cells of the macrophage lineage such as microglia, whereas TGF- $\beta_{2}$ and TGF- $\beta_{3}$ are produced by astrocytes and neurons [11, 12]. TGF- $\beta$ is secreted as a homodimer noncovalently bound to the latency-associated protein. TGF- $\beta$ latencyassociated protein may complex latent TGF- $\beta$-binding protein-1 via disulfide bonds. The active molecule needs to be released from latency-associated protein to mediate its functions via TGF- $\beta$ receptor I (TGF- $\beta$ RI) ALK-5 and TGF- $\beta$ receptor II (TGF- $\beta$ RII). The latter binds TGF- $\beta$ with high affinity (fig. 1). In the case of TGF- $\beta_{2}$, binding to this receptor requires the presence of TGF- $\beta R I I I$, a membrane-bound betaglycan. Signaling is initiated upon binding of TGF- $\beta$ dimers to the tetrameric ALK- 5 and TGF- $\beta$ RII, which leads to activation of TGF- $\beta$ RI and thereafter phosphorylation of intracellular SMAD2 and SMAD3 [for review, see ref. 13]. TGF- $\beta$ regulates Tcell survival, inhibits perforin and Fas ligand expression on CD8 $\mathrm{T}$ cells and converts $\mathrm{CD} 4^{+}, \mathrm{CD} 25^{-} \mathrm{T}$ cells into FoxP3 expressing regulatory $\mathrm{T}$ cells. Expression of a dominant negative form of TGF- $\beta$ RII in $\mathrm{CD}^{+}$cells blocks TGF- $\beta$ signaling in these cells and is associated 
with an uncontrolled CD4 ${ }^{+}$T-cell-mediated inflammatory reaction with vasculitis and perivascular cell infiltrates $[14,15]$.

\section{Role of TGF- $\beta$ in Innate Immunity in Bacterial Infections}

Cells of the mononuclear phagocyte system and PMN mediate the innate immune response in bacterial infections. In S. pneumoniae infection, phagocytosis is mainly mediated by complement which interacts with CR3 and in part with CR1, CR2 and CR4. Neutrophil activation during phagocytosis of microbes leads to respiratory burst and production of radical oxygen intermediates by the NADPH oxidase of phagocytic cells. Protective microbicidal activity is mediated by radical oxygen intermediates and granule proteases including elastase and cathepsin G [16]. Activation of PMN and monocyte-macrophages results in the secretion of chemokines and cytokines, which recruit further phagocytes into the tissue and boost the inflammatory reaction. Recognition and uptake of apoptotic cells lead to TGF- $\beta$ production by phagocytes, a process which depends on the presence of phosphatidyl serine in the cell membrane [17]. The classical view is that TGF- $\beta$ counteracts the inflammatory response.

TGF- $\beta$ suppresses: (1) the interferon- $\gamma$-induced macrophage activation including the CIITA-dependent induction of class II MHC antigens; (2) the production of expression of the proinflammatory cytokines IL-1 $\beta$, IL-6 and TNF- $\alpha$ in activated microglia; (3) the production of MMP and of chemokines (MIP-1 $\alpha$, MIP-2) which are important in migration and chemoattraction of phagocytes to the site of infection; (4) the formation of oxidative response and thereby killing of intracellular bacteria; (5) the expression of the scavenger receptors $\mathrm{CD} 3 \alpha$ and SR-A and of CD14; (6) myeloid differentiation factor 88-dependent TLR signaling, FcRI and FcRIII; (7) iNOS expression, thereby no production by phagocytes, and (8) IL-1induced signaling by enhancing production of the IL-1 receptor antagonist.

These effects of TGF- $\beta$ prevent both recognition and degradation of bacteria and interfere with microbe-induced proinflammatory activation of phagocytes [1828]. Moreover, TGF- $\beta$ inhibits lipopolysaccharide-induced septic shock in the mouse [29]. The effect of TGF$\beta$ also includes down-regulation of CD14 and binds the lipid A moiety of lipopolysaccharide, lipoteichoic acid and mycobacterial lipoarabinomannan. It is of note that

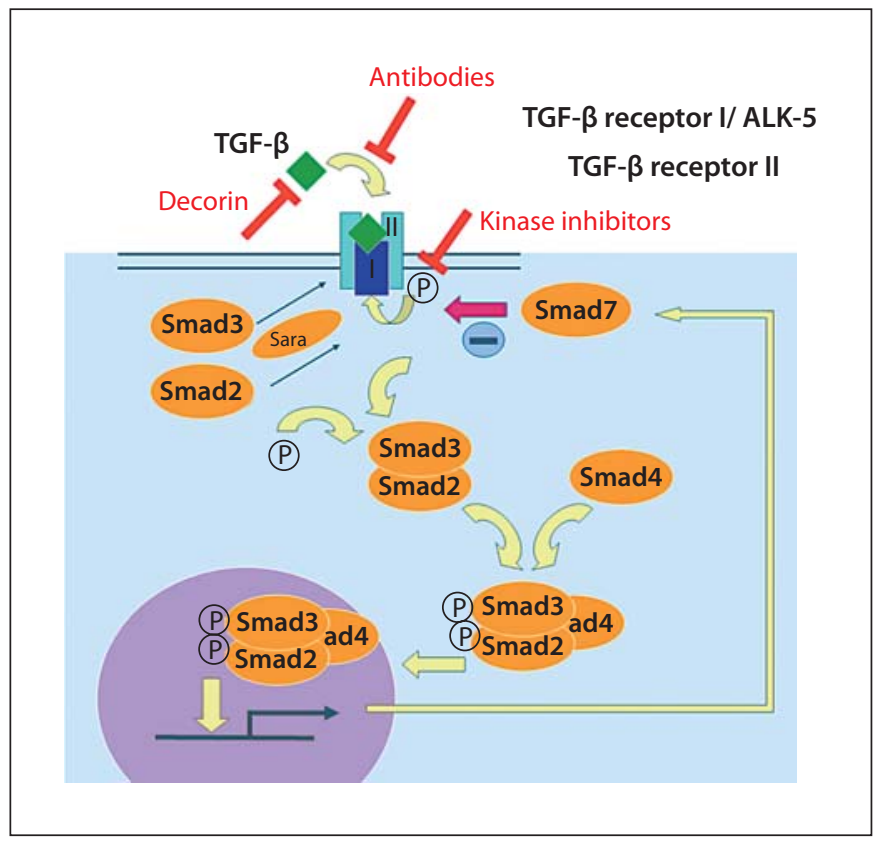

Fig. 1. TGF- $\beta$ signaling pathway and potential targets of inhibition. The activated TGF- $\beta$ RI/II complex recruits and phosphorylates the transcription factors Smad2/3, which bind Smad4 and translocate into the nucleus where they activate the transcription of target genes. Inhibitory Smad7 prevents activation of Smad2/3 by TGF- $\beta$ RI. Disruption of the signaling pathway by anti-TGF- $\beta$ and anti-TGF- $\beta$ receptor antibodies, TGF- $\beta$ decoy molecules and TGF- $\beta$ serine/threonine kinase blockers.

CD14 activates the c-Jun N-terminal kinase, which is involved in expression of TNF- $\alpha$, a major mediator of septic shock [21]. TGF- $\beta$ inhibits TNF- $\alpha$ and MIP-2 production through the crosstalk between mitogen-activated protein kinase, specifically ERK-dependent inhibition of p38 mitogen-activated protein kinase caused by up-regulation of MKP-1 [30].

The picture of the function of TGF- $\beta$ on cells of the macrophage lineage changes when analyzing the effect of the cytokine on peripheral blood monocytes. TGF- $\beta$ is chemotactic for monocytes and activates the cells to express adhesion molecules (LFA-1, VLA-3, VLA-5) and Fc$\gamma$ RIII, and to secrete IL- 1 and TNF- $\alpha$ [for review, see ref. 31]. Thus, TGF- $\beta$ deactivates tissue macrophages but activates blood monocytes. Similar to monocytes, TGF- $\beta$ is also a potent chemoattractant for PMN. The complexity of actions of TGF- $\beta$ on PMN, however, becomes evident when TGF- $\beta$ is tested on endothelial cells. TGF- $\beta$ inhibits migration through TNF- $\alpha$-activated endothelial cells in vitro and down-regulates E-selectin and VCAM-1 ex- 


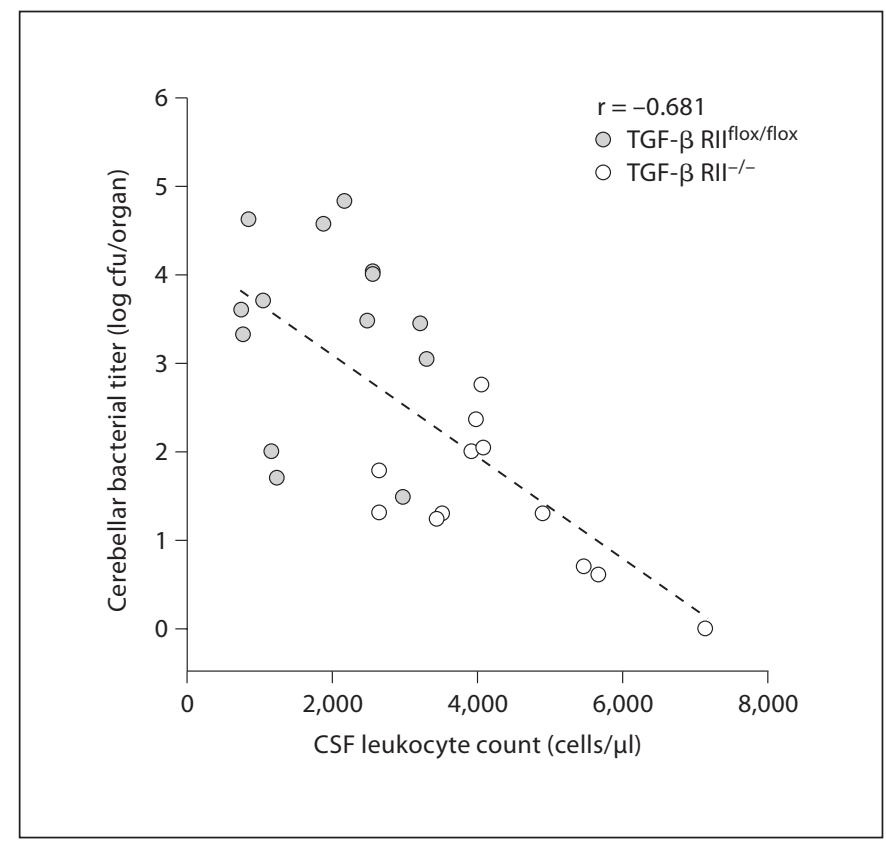

Fig. 2. High numbers of leukocytes in CSF and low bacterial titers in the CNS of $S$. pneumoniae-infected phag-TGF- $\beta \mathrm{RII}^{-/-}$mice. The higher CSF leukocyte numbers are associated with reduced cerebellar bacterial titers, indicating an improved clearance of bacteria in phag-TGF- $\beta \mathrm{RII}^{-/-}$mice.

pression $[32,33]$. Mice with double-deficient P- and Eselectins display a severe impairment of PMN influx into the meninges [34].

\section{Disruption of TGF- $\beta$ RII on Phagocytes Leads to Improved Bacterial Clearance}

To delineate and define the role of TGF- $\beta$ in innate immunity to bacterial infections, we crossed TGF$\beta$ III $^{\text {flox/flox }}$ mice with LysCre mice, thereby obtaining mice lacking TGF- $\beta$ RII on neutrophils and macrophages (phag-TGF- $\beta \mathrm{RII}^{-1-}$ mice). Given the chemotactic response of TGF- $\beta$ on these cell types and their capacity to mediate vasospasm and vasculitis and thereby secondary brain damage, PMN recruitment in a bacterial meningitis model may be impaired, thereby mitigating secondary brain damage. However, the opposite has been observed. Upon infection with $S$. pneumoniae PMN in CSF were two- to threefold higher in the phag-TGF- $\beta \mathrm{RII}^{-/-}$mice compared to controls. The amount of bacteria in the CNS correlated with the number of PMN in the CNS and was reduced 140 -fold in the phag-TGF- $\beta \mathrm{RII}^{-/-}$mice (fig. 2 ).
Thus, in bacterial meningitis TGF- $\beta$ in its active form is produced in the course of the disease and inhibits at the level of PMN their migration into the CNS, a step required for successful elimination of $S$. pneumoniae. Whether TGF- $\beta$ also counteracts phagocytosis and bacterial destruction by phagocytes remains open. However, since in phag-TGF- $\beta \mathrm{RII}^{-/-}$mice a two- to threefold increase of PMN in the CSF is paralleled by a 140 -fold decrease of the bacterial load, it is possible that TGF- $\beta$ acts at two levels: the migration process of PMN and the phagocytosis and killing process executed by PMN.

Impairment of PMN recruitment has been suggested in the following studies: (1) PMN adhesiveness to human umbilical vein endothelial cells is inhibited by TGF- $\beta$; (2) TGF- $\beta$ coinjected intratracheally with lipopolysaccharide impairs the acute neutrophilic inflammatory response, and (3) injection of TGF- $\beta$ into MRL/n mice reduces the recruitment of PMN in the thioglycollate-stimulated peritoneal exudate [35-37]. A different view on the effect of TGF- $\beta$ on PMN recruitment has been reached in other experimental systems: (1) TGF- $\beta$ is chemotactic for PMN and monocytes in vitro; (2) mice with a targeted disruption of the SMAD 3 gene - SMAD 3 binds to TGF$\beta$ receptors and mediate its signaling - impairs the chemotactic response of mutated neutrophils towards TGF$\beta$; (3) injection of TGF- $\beta$ into knee joints of rats leads to extensive recruitment of PMN and monocytes [38-41], and (4) TGF- $\beta$ induces leukocyte recruitment and improves microbial clearance when administered via intrabronchial routes to rats with Escherichia coli pneumonia [42]. Our studies show unambiguously that in bacterial infections of the CNS, TGF- $\beta$ impairs rather than stimulates PMN recruitment to the site of infection. In this context, it is of note that TGF- $\beta_{1}$ is elevated in the CSF of children with acute bacterial meningitis [43]. In this study, no correlation existed between TGF- $\beta_{1}$ levels and cell counts in the CSF on the one hand and between TGF$\beta_{1}$ levels and subsequent development of neurologic sequelae on the other. However, only 5 out of 16 patients have developed major neurological complications. Thus, the number of patients is too small to allow a definite

Fig. 3. Control mice infected with $S$. pneumoniae show widespread cortical and subcortical leukocytoclastic lesions (A), which are only occasionally observed in phag-TGF- $\beta \mathrm{RII}^{-/-}$mice (B). Immunohistology shows $\mathrm{Grl}^{+}(\mathbf{C}), \mathrm{CD}_{11} \mathrm{~b}^{+}(\mathbf{D})$, neutrophils (overlay E) in the meninges (arrowhead), in destroyed vessels (arrow) and in brain parenchyma of infected TGF- $\beta$ RII $I^{\text {flox/flox }}$ mice $(\mathbf{C}-\mathbf{F})$. F Nuclear stain with DAPI. 

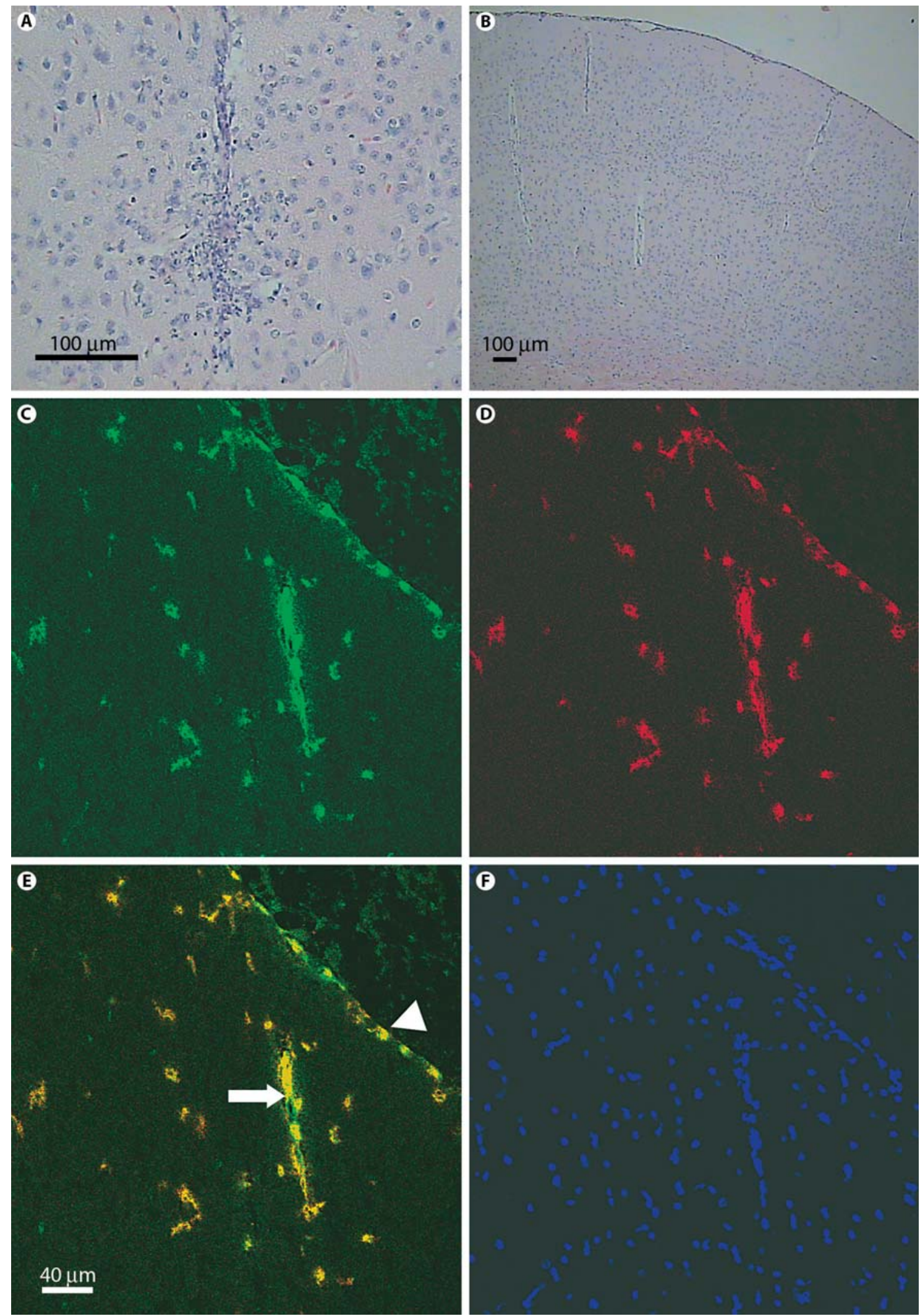
conclusion. In fact, the data do show a tendency for TGF$\beta$ to be high in patients with low leukocyte numbers and high protein content in the CSF.

\section{Bacterial Meningitis in phag-TGF- $\beta \mathrm{RII}^{-/-}$Mice: Combination of Increased PMN and Decreased Numbers of Bacteria in the CNS Prevents Secondary Brain Damage}

In the experimental meningitis model which we used to delineate the function of TGF- $\beta$, mice were inoculated with $S$. pneumoniae type 3 and $24 \mathrm{~h}$ later treated with ceftriaxone. Two days after infection, control mice developed multifocal intracerebral cortical and subcortical leukocytoclastic vasculitis of the small veins (fig. 3A, B) and blood-brain barrier damage with increased brain albumin concentrations and intracerebral pressure [44]. In phag-TGF- $\beta \mathrm{RII}^{-/-}$mice, vasculitis was one tenth as pronounced, the rise of intracranial pressure and albumin significantly reduced, and the clinical course of the disease much less severe [44]. Thus, despite pronounced CSF pleocytosis, neither vasculitis nor secondary brain damage occur in the absence of TGF- $\beta$ signaling in phagocytes, and no signs of macrophage or PMN hyperreactivity were found. Likewise, no abnormalities were detected in coagulation assays. In the light of numerous reports on deactivation of phagocytes by TGF- $\beta$ it is remarkable that there are no signs of a failure to control PMN and macrophage activity when the cells are not provided with TGF- $\beta$ RII signaling. In this context it is of note that in TGF- $\beta_{1}$ gene knockout mice, the 'spontaneous' inflammatory reaction which is observed in different organs is accompanied by increased expression of TNF- $\alpha$, IL- $1 \beta$ and iNOS. High level of expression was associated with increased TLR4 mRNA expression, the respective receptor mediating NF- $\kappa \mathrm{B}$-dependent activation of proinflammatory cytokines and iNOS [45].

Animal studies of pneumococcal meningitis show an association of low initial CSF leukocyte counts with high bacterial titers, development of intracranial complications and unfavorable outcome [46, 47]. The rise of both the intracranial pressure and the CSF protein concentration in pneumococcal meningitis in rabbits was also observed in neutropenic rabbits [48], which suggests that secondary brain complications are generated by interaction of the infectious agents with endothelial cells and/or brain parenchymal cells. Likewise, in patients with bacterial meningitis brain damage is significantly more frequent in those patients showing a low CSF pleocytosis and high bacterial numbers $[2,49]$.

\section{Future Roads to Go in the Treatment of Meningitis}

The phenotype of phag-TGF- $\beta \mathrm{RII}^{-/-}$mice observed upon infection with $S$. pneumoniae gives rise to the hope that, by blocking TGF- $\beta$ effects on innate immunity in the CNS, the clinical course of disease may be improved and the risk of secondary brain damage diminished. Different strategies can be envisaged: inactivation of TGF- $\beta$ by TGF- $\beta$-binding proteins such as decorin, by antibodies against TGF- $\beta$ and TGF- $\beta$ receptors, by inhibition of TGF- $\beta$ signaling via serine/threonine kinase blockers and by overexpression of Smad7 (fig. 1). Thus, as a first step before going into clinical studies, antibodies to TGF$\beta$, or to its receptors or small molecules which interfere with the kinase activity of the receptor, will be studied for their effectiveness in experimental bacterial meningitis.

\section{References}

1 de Gans J, van de Beek D: Dexamethasone in adults with bacterial meningitis. N Engl J Med 2002;347:1549-1556.

2 Kastenbauer S, Pfister HW: Pneumococcal meningitis in adults: spectrum of complications and prognostic factors in a series of 87 cases. Brain 2003;126:1015-1025.

3 Zwahlen A, Nydegger UE, Vaudaux P, Lambert PH, Waldvogel FA: Complement-mediated opsonic activity in normal and infected human cerebrospinal fluid: early response during bacterial meningitis. J Infect Dis 1982;145:635-646.
4 Medzhitov R, Janeway C Jr: The Toll receptor family and microbial recognition. Trends Microbiol 2000;8:452-456.

5 Koedel U, Rupprecht T, Angele B, Heesemann J, Wagner H, Pfister HW, Kirschning CJ: MyD88 is required for mounting a robust host immune response to Streptococcus pneumoniae in the CNS. Brain 2004;127: 1437-1445.

6 Paul R, Koedel U, Winkler F, Kieseier BC, Fontana A, Kopf M, Hartung HP, Pfister HW: Lack of IL-6 augments inflammatory response but decreases vascular permeability in bacterial meningitis. Brain 2003;126: 1873-1882.
7 Winkler F, Koedel U, Kastenbauer S, Pfister HW: Differential expression of nitric oxide synthases in bacterial meningitis: role of the inducible isoform for blood-brain barrier breakdown. J Infect Dis 2001;183:17491759.

8 Leppert D, Leib SL, Grygar C, Miller KM, Schaad UB, Hollander GA: Matrix metalloproteinase (MMP)-8 and MMP-9 in cerebrospinal fluid during bacterial meningitis: association with blood-brain barrier damage and neurological sequelae. Clin Infect Dis 2000;31:80-84. 
9 Kastenbauer S, Koedel U, Becker BF, Pfister HW: Oxidative stress in bacterial meningitis in humans. Neurology 2002;58:186-191.

10 Koedel U, Winkler F, Angele B, Fontana A, Pfister HW: Meningitis-associated central nervous system complications are mediated by the activation of poly(ADP-ribose) polymerase. J Cereb Blood Flow Metab 2002;22: 39-49.

11 Wrann M, Bodmer S, de Martin R, Siepl C, Hofer-Warbinek R, Frei K, Hofer E, Fontana A: T cell suppressor factor from human glioblastoma cells is a $12.5-\mathrm{kD}$ protein closely related to transforming growth factor-beta. EMBO J 1987;6:1633-1636.

12 de Martin R, Haendler B, Hofer-Warbinek R, Gaugitsch H, Wrann M, Schlusener H, Seifert JM, Bodmer S, Fontana A, Hofer E: Complementary DNA for human glioblastomaderived $\mathrm{T}$ cell suppressor factor, a novel member of the transforming growth factorbeta gene family. EMBO J 1987;6:36733677.

13 Li MO, Wan YY, Sanjabi S, Robertson AK, Flavell RA: Transforming growth factorbeta regulation of immune responses. Annu Rev Immunol 2006;24:99-146.

14 Shull MM, Ormsby I, Kier AB, Pawlowski S, Diebold RJ, Yin M, Allen R, Sidman C, Proetzel G, Calvin D, et al: Targeted disruption of the mouse transforming growth factor-beta 1 gene results in multifocal inflammatory disease. Nature 1992;359:693-699.

15 Leveen P, Larsson J, Ehinger M, Cilio CM, Sundler M, Sjostrand LJ, Holmdahl R, Karlsson S: Induced disruption of the transforming growth factor beta type II receptor gene in mice causes a lethal inflammatory disorder that is transplantable. Blood 2002;100: 560-568.

16 Tkalcevic J, Novelli M, Phylactides M, Iredale JP, Segal AW, Roes J: Impaired immunity and enhanced resistance to endotoxin in the absence of neutrophil elastase and cathepsin G. Immunity 2000;12:201-210.

17 Huynh ML, Fadok VA, Henson PM: Phosphatidylserine-dependent ingestion of apoptotic cells promotes TGF-betal secretion and the resolution of inflammation. J Clin Invest 2002;109:41-50.

18 Boutard V, Havouis R, Fouqueray B, Philippe C, Moulinoux JP, Baud L: Transforming growth factor-beta stimulates arginase activity in macrophages: implications for the regulation of macrophage cytotoxicity. J Immunol 1995;155:2077-2084.

19 Turner M, Chantry D, Katsikis P, Berger A, Brennan FM, Feldmann M: Induction of the interleukin 1 receptor antagonist protein by transforming growth factor-beta. Eur J Immunol 1991;21:1635-1639.

20 Suzumura A, Sawada M, Yamamoto $H$, Marunouchi T: Transforming growth factor-beta suppresses activation and proliferation of microglia in vitro. J Immunol 1993; $151: 2150-2158$
21 Imai K, Takeshita A, Hanazawa S: Transforming growth factor-beta inhibits lipopolysaccharide-stimulated expression of inflammatory cytokines in mouse macrophages through downregulation of activation protein 1 and CD14 receptor expression. Infect Immun 2000;68:2418-2423.

22 Naiki Y, Michelsen KS, Zhang W, Chen S, Doherty TM, Arditi M: Transforming growth factor-beta differentially inhibits MyD88-dependent, but not TRAM- and TRIF-dependent, lipopolysaccharide-induced TLR4 signaling. J Biol Chem 2005; 280:5491-5495.

23 Tridandapani S, Wardrop R, Baran CP, Wang Y, Opalek JM, Caligiuri MA, Marsh CB: TGF-beta 1 suppresses myeloid Fc gamma receptor function by regulating the expression and function of the common gamma-subunit. J Immunol 2003;170:45724577.

24 Bottalico LA, Wager RE, Agellon LB, Assoian RK, Tabas I: Transforming growth factor-beta 1 inhibits scavenger receptor activity in THP-1 human macrophages. J Biol Chem 1991;266:22866-22871.

25 Han J, Hajjar DP, Tauras JM, Feng J, Gotto AM Jr, Nicholson AC: Transforming growth factor-betal (TGF-beta1) and TGF-beta2 decrease expression of CD36, the type B scavenger receptor, through mitogen-activated protein kinase phosphorylation of peroxisome proliferator-activated receptor-gamma. J Biol Chem 2000;275:1241-1246.

26 Bogdan C, Paik J, Vodovotz Y, Nathan C: Contrasting mechanisms for suppression of macrophage cytokine release by transforming growth factor-beta and interleukin-10. J Biol Chem 1992;267:23301-23308.

27 Werner F, Jain MK, Feinberg MW, Sibinga NE, Pellacani A, Wiesel P, Chin MT, Topper JN, Perrella MA, Lee ME: Transforming growth factor-beta 1 inhibition of macrophage activation is mediated via Smad3. J Biol Chem 2000;275:36653-36658.

28 Tsunawaki S, Sporn M, Ding A, Nathan C: Deactivation of macrophages by transforming growth factor-beta. Nature 1988;334: 260-262.

29 Perrella MA, Hsieh CM, Lee WS, Shieh S, Tsai JC, Patterson C, Lowenstein CJ, Long NC, Haber E, Shore S, Lee ME: Arrest of endotoxin-induced hypotension by transforming growth factor beta1. Proc Natl Acad Sci USA 1996;93:2054-2059.

30 Xiao YQ, Malcolm K, Worthen GS, Gardai S, Schiemann WP, Fadok VA, Bratton DL, Henson PM: Cross-talk between ERK and p38 MAPK mediates selective suppression of pro-inflammatory cytokines by transforming growth factor-beta. J Biol Chem 2002; 277:14884-14893.
31 Letterio JJ, Roberts AB: Regulation of immune responses by TGF-beta. Annu Rev Immunol 1998;16:137-161.

32 Park SK, Yang WS, Lee SK, Ahn H, Park JS, Hwang O, Lee JD: TGF-beta(1) down-regulates inflammatory cytokine-induced VCAM-1 expression in cultured human glomerular endothelial cells. Nephrol Dial Transplant 2000;15:596-604.

33 Smith WB, Noack L, Khew-Goodall Y, Isenmann S, Vadas MA, Gamble JR: Transforming growth factor-beta 1 inhibits the production of IL-8 and the transmigration of neutrophils through activated endothelium. J Immunol 1996;157:360-368

34 Tang T, Frenette PS, Hynes RO, Wagner DD, Mayadas TN: Cytokine-induced meningitis is dramatically attenuated in mice deficient in endothelial selectins. J Clin Invest 1996; 97:2485-2490

35 Gamble JR, Vadas MA: Endothelial adhesiveness for blood neutrophils is inhibited by transforming growth factor-beta. Science 1988;242:97-99.

36 Ulich TR, Yin S, Guo K, Yi ES, Remick D, del Castillo J: Intratracheal injection of endotoxin and cytokines. II. Interleukin- 6 and transforming growth factor beta inhibit acute inflammation. Am J Pathol 1991;138: 1097-1101.

37 Gresham HD, Ray CJ, O'Sullivan FX: Defective neutrophil function in the autoimmune mouse strain MRL/lpr: potential role of transforming growth factor-beta. J Immunol 1991;146:3911-3921.

38 Wahl SM, Hunt DA, Wakefield LM, McCartney-Francis N, Wahl LM, Roberts AB, Sporn MB: Transforming growth factor type beta induces monocyte chemotaxis and growth factor production. Proc Natl Acad Sci USA 1987;84:5788-5792.

39 Allen JB, Manthey CL, Hand AR, Ohura K, Ellingsworth L, Wahl SM: Rapid onset synovial inflammation and hyperplasia induced by transforming growth factor beta. J Exp Med 1990;171:231-247.

40 Yang X, Letterio JJ, Lechleider RJ, Chen L, Hayman R, Gu H, Roberts AB, Deng C: Targeted disruption of SMAD3 results in impaired mucosal immunity and diminished $\mathrm{T}$ cell responsiveness to TGF-beta. EMBO J 1999;18:1280-1291.

41 Fava RA, Olsen NJ, Postlethwaite AE, Broadley KN, Davidson JM, Nanney LB, Lucas C, Townes AS: Transforming growth factor beta 1 (TGF-beta 1) induced neutrophil recruitment to synovial tissues: implications for TGF-beta-driven synovial inflammation and hyperplasia. J Exp Med 1991;173:11211132.

42 Cui X, Zeni F, Vodovitz Y, Correa-de-Araujo R, Quezado M, Roberts A, Wahl S, Danner RL, Banks SM, Gerstenberger E, Fitz Y, Natanson C, Eichacker PQ: TGF-betal increases microbial clearance but worsens lung injury during Escherichia coli pneumonia in rats. Cytokine 2003;24:115-127. 
43 Huang CC, Chang YC, Chow NH, Wang ST: Level of transforming growth factor beta 1 is elevated in cerebrospinal fluid of children with acute bacterial meningitis. J Neurol 1997;244:634-638.

44 Malipiero U, Koedel U, Pfister H-W, Levéen P, Bürki K, Reith W, Fontana A: TGFbeta receptor II gene deletion in leukocytes prevents cerebral vasculitis in bacterial meningitis. Brain 2006;129:2404-2415.
45 McCartney-Francis N, Jin W, Wahl SM: Aberrant Toll receptor expression and endotoxin hypersensitivity in mice lacking a functional TGF-beta 1 signaling pathway. J Immunol 2004;172:3814-3821.

46 Giampaolo C, Scheld M, Boyd J, Savory J, Sande M, Wills M: Leukocyte and bacterial interrelationships in experimental meningitis. Ann Neurol 1981;9:328-333.

47 Tauber MG, Kennedy SL, Tureen JH, Lowenstein DH: Experimental pneumococcal meningitis causes central nervous system pathology without inducing the $72-\mathrm{kD}$ heat shock protein. Am J Pathol 1992;141:53-60.
48 Tauber MG, Borschberg U, Sande MA: Influence of granulocytes on brain edema, intracranial pressure, and cerebrospinal fluid concentrations of lactate and protein in experimental meningitis. J Infect Dis 1988;157 456-464.

49 Felgenhauer K, Kober D: Apurulent bacterial meningitis (compartmental leucopenia in purulent meningitis). J Neurol 1985;232: 157-161. 